ETO: $81 ' 22$

ORIGINAL SCIENTIFIC PAPER

$81 ’ 373.2$

DOI: $10.19090 / h k .2019 .4 .61-77$

\title{
BAUKO János
}

Nyitrai Konstantin Filozófus Egyetem

Közép-európai Tanulmányok Kara

Magyar Nyelv- és Irodalomtudományi Intézet

Nyitra, Szlovákia

jbauko@ukf.sk

\section{NÉVSZEMIOTIKAI TÁJKÉP - TÁRSADALOM - IDENTITÁS}

\author{
Name Semiotic Landscape - Society - Identity \\ Semiotika pejzažne onomastike - društvo - identitet
}

A tanulmány a névszemiotikai tájkép - társadalom - identitás viszonyrendszerét a szlovákiai magyar települések vizuális névhasználatával szemlélteti. A névszemiotikai tájkép leírása a szocioonomasztika egyik új, dinamikusan fejlődő területe. A névszemiotikai tájkép a névtáblákon, köztereken lévő feliratokon, különböző felületeken megjelenő tulajdonneveket, valamint a nevekre utaló, neveket kísérő extralingvális jeleket foglalja magába. A társadalmi tényezők nagyban befolyásolják a névszemiotikai tájkép dinamikus változását, melynek kialakításában az egyén és társadalom, az államigazgatás, az önkormányzatok, a vállalkozói és a civil szféra is szerepet játszik. A kétnyelvü társadalomban a kisebbségi nyelven feltüntetett tulajdonnevek növelik a kisebbségi nyelv presztízsét, a kollektív identitás kifejezői, etnikai identitásjelölő funkciójuk van, identitásszimbólumoknak tekinthetők. ${ }^{1}$ Kulcsszavak: névszemiotikai tájkép, társadalom, identitás, magyar-szlovák kétnyelvü környezet

\section{Társadalom és névhasználat}

A társadalom és névhasználat kapcsolatrendszerét a szocioonomasztika vizsgálja. A társadalmi tényezők befolyásolják elsősorban a névrendszer változásait, a tulajdonnevek fejlődéstörténetét. Kiss Jenő írja Társadalom és nyelvhasználat címü könyvében, hogy ,a tulajdonnevek létrejötte és módosulása elsődle-

\footnotetext{
${ }^{1}$ A tanulmány a Tempus Közalapítvány államközi ösztöndíjának támogatásával készült.
} 
gesen társadalmi tényezők függvénye" (Kiss 1995, 278). A tulajdonnevek a társadalom termékei, kialakulásuk valószínúleg egykorú a beszédkészséggel (Hajdú 2003, 9).

Az ember amióta beszél, azóta megnevezi társait, a körülötte lévő helyeket, objektumokat, állatokat. A névadás, névhasználat antropológiai jellegzetességnek tekinthető. A nevek összekötik az embert azzal a társadalommal, közösséggel, amelybe beleszületett. A tulajdonnév egyik fö funkciója a társadalmi meghatározottságú identifikáció (lásd Blanár 1996).

Hajdú Mihály írja, hogy ,,a névtan olyannyira összefonódott a szociolingvisztikával (és a szociológiával), hogy elképzelhetetlen bármilyen jellegủ jelenkori (de akár történeti) vizsgálat is a külön-külön kidolgozott, de egymáshoz nagyon nagy mértékben hasonlító módszerek alkalmazása nélkül” (Hajdú 2003, 40).

A szocioonomasztika kutatási területei közé tartozik (bővebben lásd Bauko 2015d) a névpolitika, a névtervezés, a kisebbségi névhasználat, a névváltoztatás, a névkontaktológia, a névdivat, a névattitüd; valamint a névhasználat és az életkor, nemek, felekezetek, társadalmi csoportok stb. összefüggéseit vizsgálja. A szocioonomasztika kutatási területei nem egymástól elszigetelt részterületek, hanem kiegészítik, gyakran átfedik egymást, a tulajdonnevek társadalmi szempontok szerinti vizsgálatának egy-egy részkérdésével foglalkoznak.

A társadalmi dimenzió mellett az idő és tér dimenziója is nagyban befolyásolja a tulajdonnevek alakulását. A dimenzionális szemléletmód a névkutatásban (vö. Juhász 2011; Farkas 2014a, b) interdiszciplinaritást feltételez: az időbeliséget a diakrón onomasztika (névtörténet), a térbeliséget a geoonomasztika (névföldrajz; areális névtan, névjárástan), a társadalmi-kulturális (szociokulturális) dimenziót pedig a szocioonomasztika tanulmányozza.

\section{Identitás és névhasználat}

Hoffmann István írja a Név és identitás című tanulmányában (Hoffmann 2010), hogy a nyelvi és kulturális kötöttségeket mutató, az azonosítást szolgáló tulajdonnevek az egyén önazonosság-tudatában fontos szerepet játszanak. A neveknek ezt a funkcióját identitásjelölő szerepnek nevezi. Megemlíti, hogy a névnek nemcsak az én azonosításában, hanem a személyiség változásában, az egyén identitásépítésében is szerepe van. A nevek használatával, módosításával és új nevek adásával ugyanis folyamatosan kijelöljük, pontosítjuk a helyünket a világban.

Az identitás az önmagunkkal való azonosság vagy valamely csoporttal való azonosulás érzése, élménye. A perszonális (személyes) identitást én-azonosság- 
nak, a szociális (csoportos) identitást mi-azonosságnak nevezhetjük. Minden egyén egy (vagy több) csoport tagja is egyben, ezért a két identitástípus szoros kölcsönhatásban van egymással. Az identitás társadalmi, illetve „szociogén” jelenség (Assmann 2013, 134). Az egyén identitását befolyásolja a csoport identitása és fordítva, a csoport identitását is befolyásolja az egyén identitása, hatással van annak a csoportnak az önazonosságára, melynek részeként meghatározza önmagát.

Az identitás a személyiség és a társadalom közé elhelyezhető közvetítő kategória, amely az egyén-társadalom viszonyt reflexív módon és szimbolikus formákban építi fel. Az azonosulási folyamatokban szerepet játszanak a kognitív mozzanatok, az identitáskonstruálási müveletek lényege: önelhelyezés a szociális térben, az adott társadalomban a kultúra szerves részeiként működő „identifikációs igények” és ,identitásmodellek” felhasználásával (Pataki 1982, 300-301).

A tulajdonnév mint identitásjel különböző identitáselemekre utal(hat): nemre, életkorra, családi-rokonsági viszonyra, etnikai hovatartozásra, társadalmi szerepre, kulturális státusra, ideológiai-politikai sajátosságokra, vallási hovatartozásra stb. Mindenfajta identitás társadalmi konstrukció lévén kulturális identitás. A tulajdonnév kulturális státusa a név szemantikájának fontos részét képezi, a nevekben a társadalomnak a kultúrája rögzül (lásd Tolcsvai Nagy 2008, Hoffmann 2010).

A tulajdonneveknek etnikai identitásjelölö funkciójuk is van/lehet. A nevek utal(hat)nak az egyén, illetve közösség etnikai identitására, nyelvi hovatartozására, anyanyelvére. Az etnikai identitás én-rendszerünknek az az összetevője, amely a nemzeti-etnikai csoporthoz tartozás tudatából és élményéből származik.

\section{Névszemiotikai tájkép - társadalom - identitás}

A névszemiotikai tájkép leírása a szocioonomasztika egyik új, dinamikusan fejlődő területe, amely a feliratokban megjelenő névhasználatot érinti. A névszemiotikai tájkép a nyelvi tájkép szerves részét alkotja. A nyelvi tájkép fogalmát magyarázó meghatározások is magukba foglalják a tulajdonneveket: az adott terület, régió vagy városi agglomeráció nyelvi tájképét a hivatalos útjelző táblák, a reklámtáblák, utcanevek, helynevek, kereskedelmi egységek feliratai és kormányzati épületek hivatalos táblái adják (Landry-Bourhis 1997, 25).

A névszemiotikai tájképet a névtáblákon, a köztereken lévő feliratokon, különböző felületeken (pl. falfelületeken, sírköveken, plakátokon, tablókon) szereplő tulajdonnevek, valamint a nevekre utaló, neveket kísérő extralingvális jelek (pl. embléma, fénykép, rajz, szobor) alkotják (lásd Bauko 2019a, 137-156). 
A tulajdonnevek vizuális reprezentációját a nyilvános térben számos tényező befolyásolja. A névszemiotikai tájkép az idő-tér-társadalom dimenziójától függően dinamikusan változik, kialakításában az egyén és társadalom; az állam(igazgatás), az önkormányzatok, a vállalkozói és a civil szféra is szerepet játszik.

A nyilvános térben megjelenő tulajdonnevek nyelvisége utal a közösség, illetve egyén etnikai identitására is. A tulajdonneveket tartalmazó feliratok információt közölnek az idegenek számára a lakosság nyelvi összetételéről, a nyelv- és névpolitikáról, a nyelvek eltérő presztízséről. A névszemiotikai tájkép a társadalom és a névhasználat szoros kapcsolatára utal. A tulajdonnevek vizuális megjelenítésének értelmezésében fontos a történelmi, politikai, szociokulturális összefüggések megértése, a látható kép létét meghatározó okozati háttér feltárása.

A névszemiotikai tájképben a nyelvi ideológiák konkretizálódnak (vö. Csernicskó 2019, Lanstyák 2015, Shohamy 2006). „A nyelvi ideológiák kutatása annak elemzését jelenti, hogy a táblákat állítók, a táblákat olvasók milyen nyelven kívüli összefüggéseket, jelentéseket feltételeznek a nyelvválasztást, a feliratok szemiotikai tulajdonságait vagy elhelyezését illetően" (BarthaLaihonen-Szabó 2013, 16). A névszemiotikai tájkép kutatása során figyelmünknek ki kell terjednie a nevekre utaló extralingvális jelek vizsgálatára is, mivel ezek is hozzájárulhatnak a tulajdonnevek értelmezéséhez, vizuális megjelenítésének tanulmányozásához. Érdemes bevonni az elemzésbe, ha egy névtáblán vagy egyéb felületen a betűkön kívül más jelzések (pl. zászlók, arcképek, termékábrázolások stb.) is vannak, valamint figyelembe venni a térbeliséget is, a feliratok elhelyezését, színét, nagyságát és egyéb jellemzőit (lásd David-Mácha 2014, Gorter szerk. 2006, Jaworski-Thurlow szerk. 2010, Scollon-Scollon 2003).

A névszemiotikai tájkép a nyelvpolitika/névpolitika egyik komponense, vetülete, következménye. A névpolitika az állam vagy más, politikai tevékenységet (is) kifejtő szervezet, intézmény által a hivatalos névhasználat befolyásolása céljából kifejtett tudatos tevékenység (vö. Csernicskó 2013, Megyeri-Pálffy 2013). Az államhatalom befolyásolja a tulajdonnevek hivatalos használatát, a névtörvények szabályozzák a kisebbségi névhasználatot. A társadalmi változások, az ideológiák hatnak a névszemiotikai tájképre, és a névadási szokások átalakulásában nagy szerepet játszik az emberek hatalomhoz való alkalmazkodása. A tulajdonnév minden korban, minden társadalomban a hatalmi reprezentáció megerősítésére szolgál. A különböző korszakok névadási stratégiái tükrözik a hatalom által követendőnek ítélt ideológiát (lásd Tóth 2013). 
A továbbiakban a névszemiotikai tájkép - társadalom - identitás viszonyrendszerét a szlovákiai magyar települések vizuális névhasználatával szemléltetem.

\section{Magyar tulajdonneveket tartalmazó feliratok etnikai identitásjelölö szerepe}

A kisebbségi magyar nyelvterületek nyelvi tájképével foglalkozó publikációk nagy része érinti a névszemiotikai tájkép, vizuális tulajdonnév-használat kérdéskörét is (vö. Bartha-Laihonen-Szabó 2013; Bauko 2015a, b, c, d, 2017, 2018a, b, 2019a, b; Beregszászi 2005; Csernicskó 2019; Hires-László 2015; Karmacsi 2017; Laihonen 2012, 2013, 2014, 2015a, 2016; Laihonen-Csernicskó 2017; Misad 2014; Szoták 2013, 2015, 2016; Tódor 2019; Vukov Raffai 2013 stb.).

A többségi hatalom korlátozhatja a kisebbségi nyelvü tulajdonnevek nyilvános használatát (vö. Beregszászi-Csernicskó 2011, Csernicskó 2019, GorterMarten-Van Mensel szerk. 2012, Horony-Orosz-Szalay 2012, Kontra 2017, Laihonen 2012, Vörös 2004). Ezzel kapcsolatban születtek a „táblaháború" és „névháború” kifejezések, amelyek a hely- és személynevek hivatalos használatára vonatkoztak. Szlovákiában, a rendszerváltás után a 90-es években a szlovák nyelvtörvényre hivatkozva korlátozták a személynevek magyaros (illetve egyéb kisebbségek anyanyelvén történő) anyakönyvi bejegyzését és a kisebbségi helynevek használatát (Zalabai szerk. 1995).

A kétnyelvü társadalomban a kisebbségi (magyar) nyelven feltüntetett tulajdonnevek (egyéb feliratok) növelik a magyar nyelv presztízsét, a kollektív identitás kifejezői, etnikai identitásjelölő funkciójuk van, magyarságszimbólumoknak tekinthetők. Beregszászi Anikó írja, hogy „,a kisebbségi polgárok otthonságérzetéhez jelentősen hozzájárul az is, milyen mértékben lehet és van jelen nyelvük a kisebbségi feliratokon: láthatóvá válik-e a kisebbség nyelve, vagy csak a láthatatlan (ám kétségkívül fontos) szóbeliségre korlátozódik használata" (Beregszászi 2005, 158).

A többségi névminták erős hatást gyakorolnak a kisebbségi névhasználatra, az adott terület névszemiotikai tájképére. A többségi névalakok előnyt élveznek a kisebbségi névformákkal szemben, a fölérendelt-alárendelt viszony a tulajdonnevek vizualizálásában, térbeli viszonyában is mutatkozik: a névtáblákon a hatalmi helyzetben lévők nyelve általában felül vagy elöl van, illetve nagyobb méretü lehet.

Szlovákiában a nemzetiségi kisebbségek nyelvének használatáról szóló 1999. évi 184. számú többször módosított törvényében (módosítva a Tt. 287/2012. sz. törvényével) az olvasható, ha a Szlovák Köztársaság nemzeti kisebbség- 
hez tartozó, adott településen állandó lakhellyel rendelkező állampolgárai két egymást követő népszámlálás szerint a település lakosságának legalább $20 \%$-át ${ }^{2}$ alkotják, e községben a hivatali érintkezés során joguk van a kisebbségi nyelvet használni. Minden feliratot és a nyilvánosság tájékoztatására szánt hirdetményt, különösen az árusítóhelyeken, sportlétesítményekben, vendéglátóipari egységekben, az utcán, az út mellett és felett, az autóbusz-állomásokon és vasútállomásokon, fel lehet tüntetni a kisebbség nyelvén is.

\section{Személynév-szemiotikai tájkép}

A szlovákiai magyar települések személynév-szemiotikai tájképére jellemző, hogy a névtáblákon, egyéb felületeken szlovák és magyar személynévalakok egyaránt előfordulnak. A személynevek nyilvános térben való megjelenítési formáját nem írják elő a névtörvények.

A személynevek vizualizálásában a szlovákos névformák használata dominál, ekkor a névsorrend keresztnév + családnév, és a nők családnevéhez az -ová végződés kapcsolódik. A magyaros névformák, illetve névrészek a névviselő etnikai identitására utalnak. A névtáblán erre utal a magyar keresztnév feltüntetése, illetve a nőknél az -ová családnévképző elhagyása (lásd 1-2. kép): pl. Veronika Mészáros, András Marsal (magyar keresztnévalak + magyar családnévforma + szlovákos névsorrend); Stubendek Mária, Vörös Attila (magyar családnévforma + magyar, illetve mindkét nyelvben azonos keresztnévalak + magyaros névsorrend). Amennyiben a névviselö titulussal is rendelkezik, az is megtalálható a neve mellett.

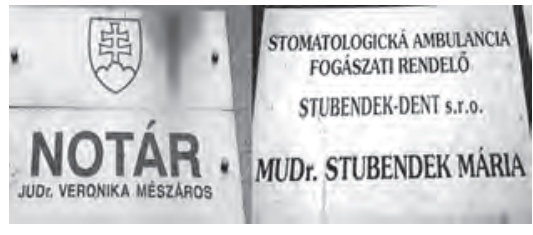

1. kép: Nők magyaros névformái a névtáblákon

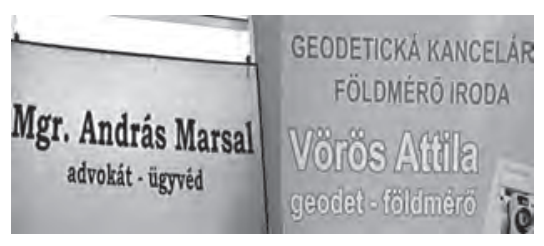

2. kép: Férfiak magyaros névformái a névtáblákon

\footnotetext{
${ }^{2}$ A törvény legutóbbi, Tt. 287/2012. számú módosításában már a 15\%-os kvóta szerepel, ez a 2021-es szlovákiai népszámlálástól számítódik majd.
} 
A szlovákiai magyarokra jellemző a kettős személynévhasználat, a család- és keresztnévnek kétféle alakváltozatban való használata. Magyar nyelvü kontextusban a magyar névformákat részesítik előnyben, a szlovák nyelvet elváró kontextusban pedig a többségi nyelvhez alkalmazkodó névalakokat használják. A személy kettős identitására utalhat, ha a keresztnév magyar és szlovák névpárja egyszerre, egy névalakban (pl. Ernest Kocsis Ernó) szerepel névjegykártyákon, szórólapokon, nyomtatott kiadványokon stb. A 3. képen látható, kettős személynévhasználatra utaló névjegykártyán a személynév Juraj Mészáros György formában van feltüntetve: a két keresztnév közé ékelődik a családnév, az első helyen áll a magyar keresztnév szlovák névpárja (Juraj), ezt követi a családnév (Mészáros), majd a magyar keresztnév (György). A hibrid, két nyelv névelemeiből álló névalak egyszerre idézi fel a személynév szlovák (Juraj Mészáros) és magyar (Mészáros György) változatát is.

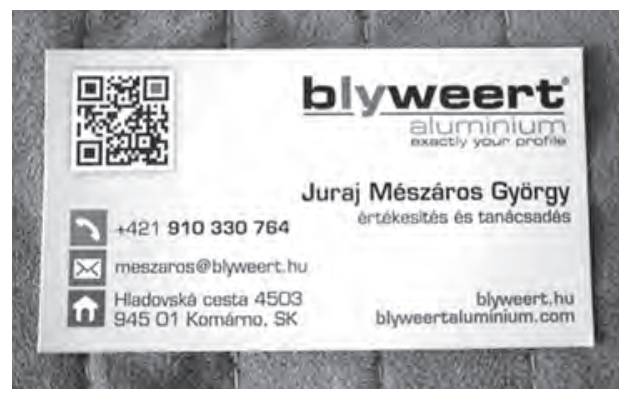

3. kép: Kettős személynévhasználatra utaló névjegykártya

Egyes felületeken a magyar névalakok dominálnak. Gyakori, hogy az egyébként szlovákul anyakönyvezett személynevet az egyén/közösség által használatos magyaros formában tüntetik fel. A szlovákiai magyar tannyelvủ iskolákban található névtáblákon, tablókon a tanárok és diákok család- és keresztneve általában magyaros formában van feltüntetve. A szlovákiai magyar települések temetőiben nagy számban találhatók a sírfeliratokon magyarul feltüntetett személynevek. A magyaros névalakok, illetve a sírfeliraton található szövegek utalnak az egykori névviselö(k) etnikai identitására. Az önkormányzati választási plakátokon megfigyelhető, hogy a magyar identitású jelöltek személyneve magyaros formában szerepel (lásd 4. kép), amely sok esetben nem azonos a névviselő anyakönyvezett névváltozatával. 


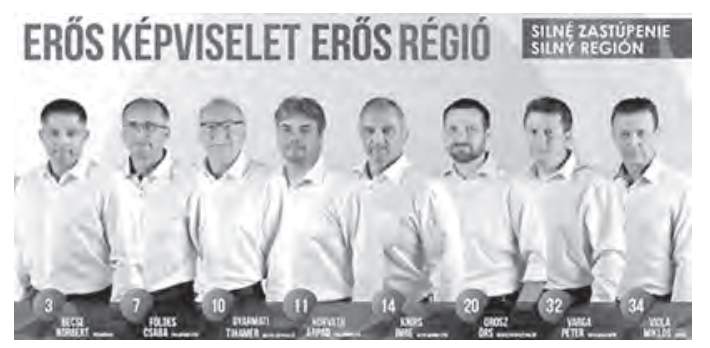

4. kép: Magyar személynévalakokat feltüntető választási plakát

\section{Helynév-szemiotikai tájkép}

Szlovákia magyarlakta településein a helynév-szemiotikai tájképre (elsősorban a helységneveket, utcaneveket illetően) a kétnyelvüség jellemző: az első helyen általában az államnyelvi (szlovák) névalak áll, ezt követi a kisebbségi (magyar) névpárja.

2019-ben kezdték kihelyezni az azonos méretű helységnévtáblákat a szlovákiai kisebbségi településeken a 9/2009-es belügyminisztériumi rendelet 19/2018-as módosítása értelmében: a felső táblán található fekete keretben, fehér alapon és fekete nyomtatott nagybetűvel a szlovák helységnév; alatta egy önálló, azonos méretủ névtáblán szerepel kék keretben, fehér alapon és fekete nyomtatott nagybetűvel a magyar településnév. Az azonos méretü táblák a kisebbségi és a többségi névpár egyenrangúságát is jelölik. Arra is van példa, hogy az újonnan kihelyezett névtáblákon a magyar névforma nagyobb betütípussal szerepel, mint az államnyelvi névpárja (lásd 5. kép: Dolný Bar-Albár).

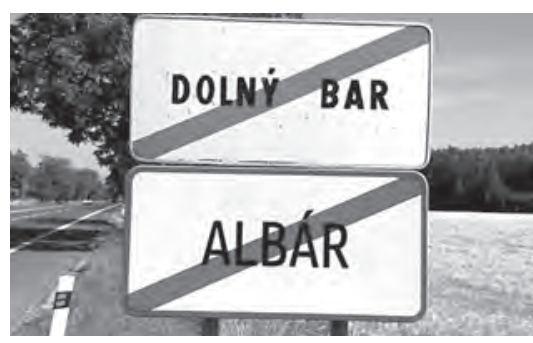

5. kép: Szlovák-magyar kétnyelvü helységnévtábla

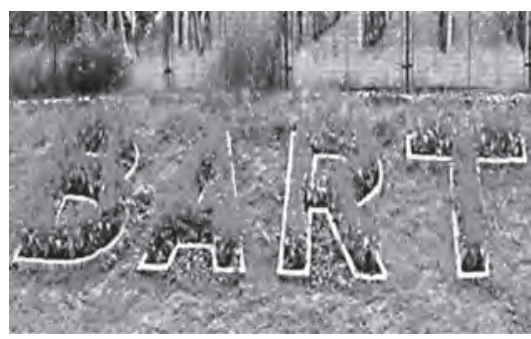

6. kép: Virágokból kirakott magyar helységnév

A helyi lakosok a kétnyelvü helységnév közül a település magyar nevének használatát preferálhatják az adott helységben. Bart / Bruty községben a 2011-es népszámlálás alapján a lakosok több mint 90\%-a magyar nemzetiségü. A magyarlakta település kezdetét és végét jelző közúti táblán a kétnyelvű hely- 
ségnév szerepel. Ezenkívül a faluban találhatunk egy virágokból kirakott magyar nyelvü Bart feliratot (lásd 6. kép). A piros-fehér-zöld színű felirat Magyarország állami színeit idézi fel, s a helyi lakosok magyar identitásáról árulkodik.

Nagykeszi / Vel'ké Kosihy község központjában látható egy „, hello NAGYKESZI" felirat (lásd 7. kép), amely arra is utal, hogy a helybeliek a régebbi, magyar nyelvü helységnévformát részesítik előnyben. A 2011-es népszámlálás alapján a falu lakosainak mintegy $78 \%$-a vallja magát magyar nemzetiségünek.

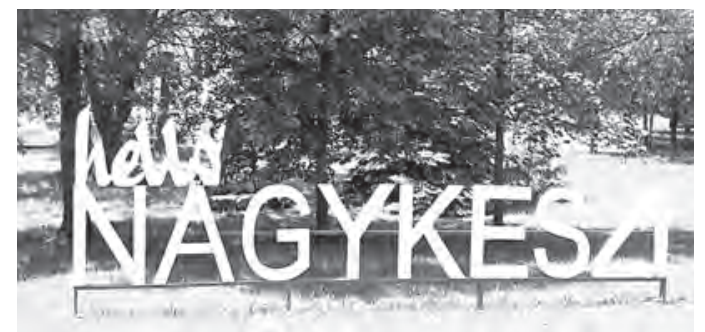

7. kép: Magyar helységnevet preferáló felirat

Az 1999. évi 184. számú kisebbségi nyelvhasználati törvény szerint a települések az utcaneveket és más helyi földrajzi helyneveket kisebbségi nyelven is feltüntethetik. A kétnyelvű utcanévtáblákon az első helyen általában a szlovák név szerepel, és alatta áll a magyar név. Nyékvárkony községben a magyar utcanév megelőzi a szlovák párját (lásd 8. kép: Iskola utca - Školská ulica), ami a helyi közösség magyar identitásáról is árulkodik, a 2011-es népszámlálás szerint a település lakosainak mintegy $85 \%$-a magyar nemzetiségú.

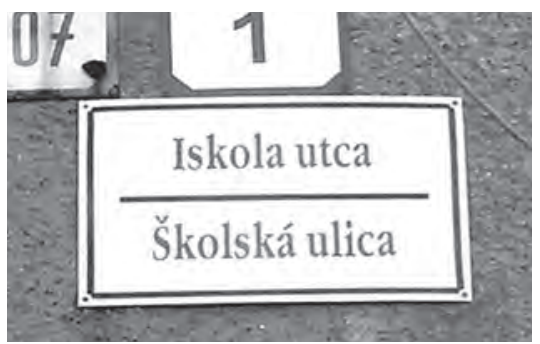

8. kép: Magyar-szlovák kétnyelvü utcanévtábla

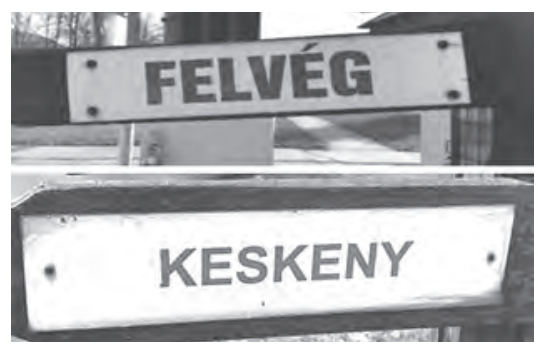

9. kép: Nem hivatalos magyar utcanévtáblák

Egyes településeken, amelyekben nincsenek hivatalos kétnyelvü utcanevek, láthatunk nem standard ucanévtáblákat is. Ajnácskő faluban a helyi lakosok nem hivatalos magyar nyelvü utcanévtáblákat helyeztek el a közterületen, melyek az élőnyelvben használatos helyneveket (Felvég, Keskeny) tüntetik fel (lásd 9. kép). 


\section{Intézménynév-szemiotikai tájkép}

A szlovákiai magyar települések intézménynév-szemiotikai tájképe variábilis: az állami intézményekben (pl. hivatalok, magyar tannyelvü iskolák) a kétnyelvü feliratok dominálnak, a magánszférába tartozó intézmények (pl. üzletek, hotelek, éttermek) esetében gyakoribbak az egynyelvü (többnyire angol nyelvü) megnevezések.

Az állami intézményekben (iskolák, hivatalok, múzeumok, könyvtárak, müvelödési és egészségügyi központok stb.) a kétnyelvü szlovák-magyar névtáblák dominálnak. A magyar nyelvü megnevezés ugyanakkora nagyságú betükkel, illetve azonos betütípussal szedve többnyire az intézmény szlovák neve alatt található. Arra is van példa, hogy a névtáblán a magyar megnevezés megelőzi a szlovák névpárját, pl. A Magyar Köztársaság Kulturális Intézete Kultúrny inštitút Mad'arskej republiky, Magyar Alkotó Müvészek Szlovákiai Egyesülete-Spolok mad'arských tvorivých umelcov na Slovensku, Szövetség a Közös Célokért-Združenie za spoločné ciele, Jókai Közmüvelödési és Múzeum Egyesület - Jókaiho všeobecnovzdelávacie a múzejné združenie (lásd 10. kép).

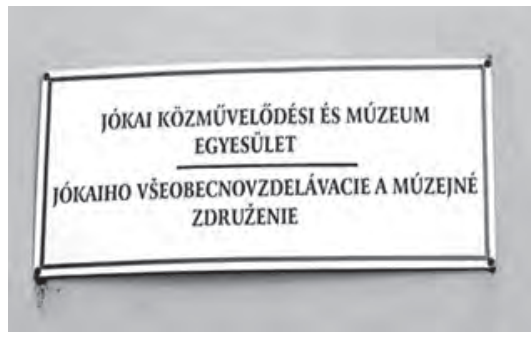

10. kép: Magyar-szlovák intézménynévtábla

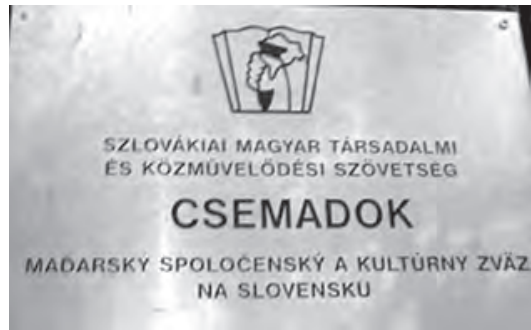

11. kép: Magyar-szlovák intézménynévtábla

A társadalmi változások motiválhatják már meglévő intézmények neveinek megváltoztatását is. A CSEMADOK mozaiknév eredetileg a Csehszlovákiai Magyar Dolgozók Kultúregyesülete megnevezés rövidítéseként született 1949ben. Napjainkban továbbra is használatos a beszélőközösségben ismert, elterjedt rövidített alakváltozat, de Csehszlovákia szétesése, Szlovákia 1993-as önállósulása következtében az intézmény teljes neve már nem vonatkozott a rendszerváltozás előtti jelentésére, ezért megváltozott. A névtáblán (lásd 11. kép) a magyar megnevezés (Szlovákiai Magyar Társadalmi és Közmüvelödési Szövetség - CSEMADOK) megelőzi a szlovák párját (Mad’arský spoločenský a kultúrny zväz na Slovensku), amely fel sincs tüntetve az intézmény (magyar nyelvü) honlapján. 
Az utóbbi évtizedekben létrehozott magyar intézmények, szervezetek névadására jellemző, hogy gyakran magyar személyiségek nevét veszik fel.

Az 1989-es rendszerváltozást követően több szlovákiai magyar iskola kérvényezte az intézmény magyar megnevezésének megváltoztatását, s többnyire a régióhoz kötődő vagy a magyar történelemből ismert magyar személyiség nevét vette fel az intézménynévbe: A magyar tannyelvü iskolák névtábláján elsőként a szlovák megnevezés van feltüntetve, és azt követi a magyar névmegfelelő: pl. Gymnázium a základná škola Sándora Máraiho s vyučovacím jazykom mad’arským - Márai Sándor Magyar Tanitási Nyelvü Gimnázium és Alapiskola (Kassa), Základná škola s vyučovacím jazykom mad’arským Móra Jókaiho Jókai Mór Magyar Tanitási Nyelvü Alapiskola (Komárom). Egyes felületeken kizárólag magyarul is fel lehet tüntetve az intézmény neve. Búcs községben látható a fába vésett Szivárvány Óvoda felirat (lásd 12. kép). A szivárvány alakú farészt két kopjafa tartja, ami szintén magyarságszimbólumnak tekinthető. Az óvoda honlapján arról is olvashatunk, hogy a megnevezés egyes betüihez fogalmakat is társítottak: SZ - szeretet, I - ismeret, V - vidámság, Á - állandóság, $\mathrm{R}$ - ráébredés, $\mathrm{V}$ - varázslat, Á - álmok, $\mathrm{NY}$ - nyugalom.

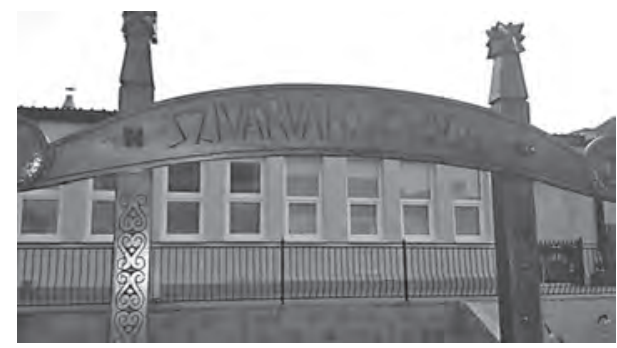

12. kép: Magyar óvodanév

A magánszférába tartozó intézmények (pl. üzletek, hotelok, éttermek) esetében a tulajdonnevet tartalmazó feliratok nyelvi szempontból sokszínűek. A magánintézményekre a szlovák-magyar kétnyelvű megnevezések kevésbé jellemzőek, az egynyelvü (szlovák, magyar, angol vagy egyéb idegen eredetü) feliratok dominálnak, a névadásban nagyobb a szabadság, bármilyen szó intézménynévvé válhat.

Nyelvileg hibrid megnevezések is szerepelhetnek a névtáblán, az egyik névrész szlovák, a másik magyar nyelvü lehet: pl. Hostinec Vándor, Hostinec Zöldfa, Reštaurácia Fehér Ló (kocsmanevek).

\footnotetext{
${ }^{3}$ Az alapiskola 'általános iskola’ közszó a szlovákiai magyar standard része, a szlovák základná škola tükörfordításaként keletkezett.
} 
Arra is van példa, hogy kizárólag magyar nyelven használatosak egyes megnevezések: Bástya Csárda, Szekeres Csárda, Pozsonyi Csárda, Budapest Kávézó, Jó Bástya Csárda (lásd 13. kép). A magyar egynyelvű tulajdonnevek az adott intézmény névadóinak nyelvi identitásáról, attitüdjéről, az anyanyelvi névhasználat preferálásáról is árulkodnak.

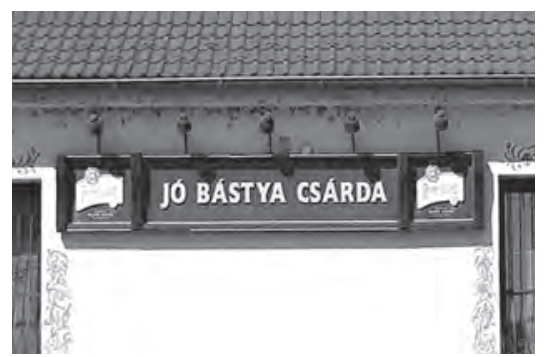

13. kép: Magyar csárdanév

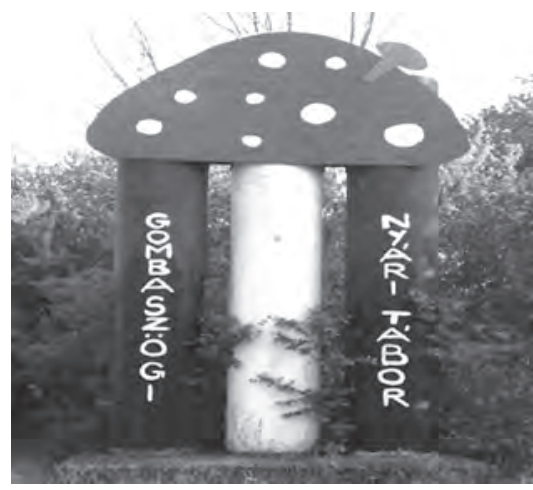

14. kép: Magyar intézménynév

A tulajdonnevek, névrészek képi megjelenítése is megfigyelhető a névszemiotikai tájképben. A Gombaszögi Nyári Tábor (a szlovákiai magyar fiatalok egyik legnagyobb nyári rendezvénye: egyhetes fesztivál, szabadegyetem és táborozás) megnevezésből a Gombaszög névrész vizualizálódik képi formában: a gomba formájú felületen szerepel a felirat, s a gomba kalapjába egy szög vésődik. Ez népetimológiás helységnév-interpretációra utal, szó szerint értelmezi a Gombaszög helynevet (gomba + szög). A tudományos etimológiai magyarázat szerint a településnév sok gombát termő szegletre (szeg szög 'sarok, szeglet, zug') utal (Kiss 1988, 521).

\section{Összegzés}

A nyelvi tájkép szerves részét alkotja a névszemiotikai tájkép, amely a névtáblákon, köztereken lévő feliratokon, különböző felületeken megjelenő tulajdonneveket, valamint a nevekre utaló, neveket kísérő extralingvális jeleket foglalja magába.

A társadalmi tényezők nagyban befolyásolják a névszemiotikai tájkép dinamikus változását. A névszemiotikai tájkép kialakításában az egyén és társadalom, az államigazgatás, az önkormányzatok, a vállalkozói és a civil szféra is szerepet játszik. A kisebbségi tulajdonnevek nyilvános térben való megje- 
lenítésének módját az államhatalom által jóváhagyott jogszabályok írják elő. Vannak azonban olyan szabályozatlan területek, ahol a tulajdonnevek nyelvi megformálása szabad választás kérdése. Ide sorolhatjuk a privát szférához tartozó névmegjelenítéseket (pl. egyéni névtáblák, névjegykártyák stb.), a temetők, magánintézmények (pl. vendéglők, üzletek) világát, ahol a nevek megformálása a feliratkészítőktől függ.

Fontos nyelvstratégiai kérdés a magyar nevek táblákon, feliratokon való megjelenítése. Az erős magyar közösséggel rendelkező szlovákiai magyar településeken terjedőben van a magyar feliratok használata.

A magyar nyelven feltüntetett tulajdonnevek (egyéb feliratok) növelik a magyar nyelv presztízsét, a kollektív identitás kifejezői, etnikai identitásjelölő funkciójuk van, magyarságszimbólumoknak tekinthetők.

\section{Irodalom}

Assmann, Jan. 2013. A kulturális emlékezet: irás, emlékezés és politikai identitás a korai magaskultúrákban. Budapest: Atlantisz.

Bartha Csilla-Laihonen, Petteri-Szabó Tamás Péter. 2013. Nyelvi tájkép kisebbségben és többségben: egy új kutatási területről. Pro Minoritate 23 (3): 13-28.

Bauko János. 2015a. Kétnyelvűség és névszemiotikai tájkép: Kisebbségi névtörvények és vizuális tulajdonnév-használat Szlovákiában. Névtani Értesitő 37. 179-194.

Bauko János. 2015b. Kétnyelvü névszemiotikai tájkép. In A nyelv dimenziói: Tanulmányok Juhász Dezső tiszteletére, szerk. Bárth M. János-Bodó Csanád-Kocsis Zsuzsanna. 323-334. Budapest: ELTE BTK.

Bauko János. 2015c. Tulajdonnév - kép - hatalom. In Nyelvészet, müvészet, hatalom: Írások Tóth Szergej tiszteletére, szerk. Gaál Zsuzsanna. 231-244. Szeged: Szegedi Egyetemi Kiadó.

Bauko János. 2015d. Bevezetés a szocioonomasztikába. Nyitra: Nyitrai Konstantin Filozófus Egyetem.

Bauko János. 2017. Tulajdonnevekre utaló extralingvális jelek a névszemiotikai tájképben. In ,A véges végtelen”: Tanulmányok Vörös Ferenc 60. születésnapjára, szerk. Hajba Renáta-Tóth Péter. 13-26. Szombathely: Savaria University Press.

Bauko János. 2018a. Komárom (Komárno) névszemiotikai tájképe. In Nyelvi tájkép, nyelvi sokszinüség: Nyelvhasználat, nyelvi tájkép és gazdasági élet I., szerk. Tódor Erika-Mária-Tankó Enikő-Dégi Zsuzsanna. 55-70. Kolozsvár: Scientia.

Bauko János. 2018b. Állatok a kétnyelvű névszemiotikai tájképben. In Állati jelek, képek és terek II. Jel-Kép-Tér sorozat 3, szerk. Szirmai Éva-Tóth Szergej-Újvári Edit. 207-219. Szeged: Szegedi Egyetemi Kiadó, Juhász Gyula Felsőoktatási Kiadó. 
Bauko János. 2019a. Társadalom és névhasználat: Magyar névtani kutatások Szlovákiában. Budapest: Magyar Nyelvtudományi Társaság és az ELTE BTK Magyar Nyelvtörténeti, Szociolingvisztikai, Dialektológiai Tanszéke. http://real.mtak.hu/ id/eprint/99620 (2019. okt. 24.)

Bauko János. 2019b. Propriálno-semiotický obraz bilingválnych obcí Slovenska. In Konvergencie a divergencie v propriálnej sfére: 20. slovenská onomastická konferencia, eds. Chomová, Alexandra-Krško, Jaromír-Valentová, Iveta. 138-148. Bratislava: Veda, vydavatel'stvo Slovenskej akadémie vied.

Beregszászi Anikó. 2005. „Csata” a szimbolikus térért, avagy a látható/láthatatlan anyanyelv. In Kárpátalja: Társadalomtudományi tanulmányok, szerk. Beregszászi Anikó-Papp Richárd. 158-178. Budapest-Beregszász: MTA Etnikai-nemzeti Kisebbségkutató Intézet-II. Rákóczi Ferenc Kárpátaljai Magyar Főiskola.

Blanár, Vincent. 1996. Teória vlastného mena: Status, organizácia a fungovanie v spoločenskej komunikácii. Bratislava: Veda, vydavatel'stvo Slovenskej akadémie vied.

Csernicskó István. 2013. Államok, nyelvek, államnyelvek. Nyelvpolitika a mai Kárpátalja területén (1867-2010). Budapest: Gondolat Kiadó.

Csernicskó István. 2019. Fények és árnyak: Kárpátalja nyelvi tájképéből. Ungvár: Autdor-Shark.

David, Jaroslav-Mácha, Přemysl. 2014. Názvy mist: Pamět', identita, kulturní dědictví. Ostrava: Ostravská univerzita v Ostravě.

Farkas Tamás. 2014a. Dimenzionális szemlélet a névkutatásban: Általános kérdések és a családnévkutatás példája. Névtani Értesítő 36. 9-22.

Farkas Tamás. 2014b. Névkutatás és dimenzionális nyelvészet: Két esettanulmány. In Elmélet és módszer: Nyelvészeti tanulmányok, szerk. Laczkó Krisztina-Tátrai Szilárd. 39-65. Budapest: Eötvös Kollégium.

Gorter, Durk ed. 2006. Linguistic Landscape: A New Approach to Multilingualism. Clevedon-Buffalo-Toronto: Multilingual Matters.

Gorter, Durk-Marten, Heiko F.-Van Mensel, Luk eds. 2012. Minority Languages in the Linguistic Landscape. Basingstoke: Palgrave Macmillan.

Hajdú Mihály. 2003. Általános és magyar névtan: Személynevek. Budapest: Osiris Kiadó.

Hires-László Kornélia. 2015. Nyelvi tájkép és etnicitás Beregszászon. In Nyelvoktatás, kétnyelvüség, nyelvi tájkép, szerk. Márku Anita-Hires-László Kornélia. 160-185. Ungvár: Autdor-Shark.

Hoffmann István. 2010. Név és identitás. Magyar Nyelvjárások 48. 49-58.

Horony Ákos-Orosz Örs-Szalay Zoltán. 2012. A hely nevei, a nyelv helyei: A kisebbségi nyelvi jogok története Szlovákiában 1918-2012. Jelek a térben 4. Somorja: Fórum Kisebbségkutató Intézet.

Jaworski, Adam-Thurlow, Crispin eds. 2010. Semiotic landscapes: Language, image, space. London: Continuum. 
Juhász Dezső. 2011. Dimenzionális nyelvészet. In Nyelvészetről mindenkinek: 77 nyelvészeti összefoglaló, szerk. Balázs Géza. 61-64. Budapest: Inter Kultúra-, Nyelv- és Médiakutató Központ Nonprofit Kft.

Karmacsi Zoltán. 2017. A nyelvi tájkép változásának egy aspektusa. In Többnyelvüség, regionalitás, nyelvoktatás: Tanulmányok a Hodinka Antal Nyelvészeti Kutatóközpont kutatásaiból III., szerk. Márku Anita-Tóth Enikő. 54-60. Ungvár: „RIK-U”.

Kiss Jenő. 1995. Társadalom és nyelvhasználat. Budapest: Nemzetközi Tankönyvkiadó.

Kiss Lajos. 1988. Földrajzi nevek etimológiai szótára I. Budapest: Akadémiai Kiadó.

Kontra Miklós. 2017. Megjegyzések kétnyelvü magyarok hely- és személyneveiről. Névtani Értesítö 39. 33-40.

Laihonen, Petteri. 2012. Nyelvi tájkép egy csallóközi és egy mátyusföldi faluban. Fórum Társadalomtudományi Szemle 3. 27-49.

Laihonen, Petteri. 2013. Csíkszentdomokosi nyelvi tájkép. Székelyföld 17 (7): 157-177.

Laihonen, Petteri. 2014. Hungarian private linguistic landscape in South-West Slovakia. In Dangers and developments: On Language Diversity in a Changing World. Studies in European Language Diversity 34, ed. Laakso, Johanna. 86-106. Research consortium ELDIA c/o, European Language Diversity for All.

Laihonen, Petteri. 2015a. Linguistic landscapes of a minoritized regional majority: Language ideologies among Hungarians in South-West Slovakia. In Dimensions of Sociolinguistic Landscapes in Europe Materials and Methodological Solutions, eds. Laitinen, Mikko-Zabrodskaja, Anastassia. 171-198. Frankfurt am Main: Peter Lang.

Laihonen, Petteri. 2015b. Indexing the Local, State and Global in the Contemporary Linguistic Landscape of a Hungarian Town in Slovakia. In Jazyk v politických, ideologických a interkultúrnych vzt'ahoch: Sociolinguistica Slovaca 8, eds. Wachtarczyková, Jana-Satinská, Lucia-Ondrejovič, Slavomír. 280-301. Bratislava: Veda, vydavatel'stvo SAV.

Laihonen, Petteri-Csernicskó István. 2017. Kísérlet egy összehasonlító vizsgálatra: a nyelvi tájkép dél-szlovákiai, székelyföldi és kárpátaljai falvakban. Regio 25 (3): 50-81. https://doi.org/10.17355/rkkpt.v25i3.172 (2019. okt. 26.)

Landry, Rodrigue-Bourhis, Richard. 1997. Linguistic landscape and ethnolinguistic vitality. Journal of Language and Social Psychology (16): 23-49. https://doi.org/ 10.1177/0261927x970161002 (2019. okt. 25.)

Lanstyák István. 2015. Nyelvalakítás-névalakítás. A tulajdonnevekkel kapcsolatos nyelvi problémák kezelése a nyelvmenedzselés-elmélet keretében. In A nyelvföldrajztól a névföldrajzig V.: Interetnikus kapcsolatok, szerk. Vörös Ferenc-Misad Katalin. 43-75. Pozsony: Szenczi Molnár Albert Egyesület.

Megyeri-Pálffi Zoltán. 2013. Név és jog: A névviselés jogi szabályozásának fejlődése Magyarországon. Budapest: Gondolat Kiadó. 
Misad Katalin. 2014. Mutatvány Dunaszerdahely intézményeinek vizuális nyelvhasználatából. In Sokszinü nyelvészet - nyelvi sokszinüség a 21. század elején: Írások Kolláth Anna tiszteletére, szerk. Gróf Annamária-N. Császi Ildikó-Szoták Szilvia. 243-253. Budapest: Tinta Könyvkiadó.

Pataki Ferenc. 1982. Az én és a társadalmi azonosságtudat. Budapest: Kossuth Könyvkiadó.

Scollon, Ron-Scollon, Suzie Wong. 2003. Discourses in Place: Language in the Material World. London: Routledge. https://doi.org/10.4324/9780203422724 (2019. okt. 29.)

Shohamy, Elana. 2006. Language policy: Hidden agendas and new approaches. London: Routledge.

Szoták Szilvia. 2013. Nyelvi tájkép az Örvidéken. In A közép-európaiság dicsérete és kritikája, szerk. Fedinec Csilla-Illyés Zoltán-Simon Attila-Vizi Balázs. 515-537. Pozsony: Kalligram Kiadó.

Szoták Szilvia. 2015. Családnevek és kétnyelvüség az őrvidéki temetőkben: Alsóőr. In A nyelvföldrajztól a névföldrajzig VI.: Határtalan névföldrajz, szerk. Vörös Ferenc. 131-145. Unterwart/Alsóőr-Budapest: UMIZ-Imre Samu Nyelvi Intézet.

Szoták Szilvia. 2016. Magyar nyelv és magyar népcsoport Burgenlandban: Nyelvi tájképek vizsgálata a többnyelvüség kontextusában. PhD-értekezés. Pécs: Pécsi Tudományegyetem.

Tódor Erika-Mária. 2019. Hétköznapi kétnyelvüség: Nyelvhasználat, iskolai nyelvi tájkép és nyelvi én a romániai magyar iskolákban. Budapest: Ráció Kiadó-Szépirodalmi Figyelő Alapítvány.

Tolcsvai Nagy Gábor. 2008. A tulajdonnév jelentése. In Név és valóság: A VI. Magyar Névtudományi Konferencia elöadásai. A Károli Gáspár Református Egyetem Magyar Nyelvtudományi Tanszékének Kiadványai 1, szerk. Bölcskei Andrea-N. Császi Ildikó. 30-41. Budapest: Károli Gáspár Református Egyetem BTK Magyar Nyelvtudományi Tanszéke.

Tóth Szergej. 2013. Nyelv, kép, hatalom. Alkalmazott Nyelvészeti Mesterfüzetek 4. 2., javított kiadás. Szeged: Szegedi Egyetemi Kiadó, Juhász Gyula Felsőoktatási Kiadó.

Vörös Ferenc. 2004. Névpolitika a Felvidéken. In A magyar nyelvi kultúra jelene és jövője, szerk. Balázs Géza. 367-381. Budapest: MTA Társadalomkutató Központ.

Vukov Raffai Éva. 2013. A kódolt identitás mint a nyelvi tájkép alapeleme. In Tudományos diszkurzusok: Konferenciakötet. Vajdasági Magyar Tudóstalálkozó 2013, szerk. Berényi János. 178-184. Újvidék: Vajdasági Magyar Akadémiai Tanács.

Zalabai Zsigmond szerk. 1995. Mit ér a nyelvünk, ha magyar?: A ,táblaháború” és a „,névháború” szlovákiai magyar sajtódokumentumaiból 1990-1994. Pozsony: Kallig-ram Könyvkiadó. 


\section{NAME SEMIOTIC LANDSCAPE - SOCIETY - IDENTITY}

The paper examines the connections between bilingualism and the name semiotic landscape focusing especially on the name semiotic landscape of Slovakian settlements populated by Hungarian minorities, as well as on naming laws affecting the visual use of proper names in Slovakia. Name-semiotic landscape is one of the new dynamically developing fields of socionomastics. The name semiotic landscape consists of proper names (especially personal names, place names and the names of institutions) which appear on name plates, notices in public places and other surfaces (e.g. posters, wall surfaces, gravestones, tableaux), as well as extralinguistic signs referring to names. The author explores the extent to which in Slovakian settlements with Hungarian minorities, minority language rights are respected in the visual use of proper names; whether or not native name use is increasing; and also examines the presence of signs and notices including Hungarian proper names. Social factors greatly influence the dynamic change in the name semiotic landscape. The paper describes the semiotic landscape characteristics of Slovakian settlements populated by Hungarian minorities with respect to each name type: personal names, place names and the names of institutions. In bilingual society proper names appearing in a minority language increase the prestige of the minority language, they express collective identity and can be considered as symbols of identity.

Keywords: proper name, name semiotic landscape, society, bilingualism, identity

\section{SEMIOTIKA PEJZAŽNE ONOMASTIKE - DRUŠTVO - IDENTITET}

U radu se prikazuje struktura odnosa između semiotike pejzažne onomastike, društva i identiteta na primeru mađarskih naselja u Slovačkoj. Opis pejzažne onomastike predstavlja novu granu socioonomastike koja pokazuje dinamični razvoj. Pejzažna onomastika podrazumeva imena ili natpise koji se nalaze ispisani na javnim mestima, lična imena koja su istaknuta na raznim površinama, kao i ekstralingvalne znake koji ukazuju na nazive i nalaze se u pratnji imena. Društveni činioci u velikoj meri utiču na dinamičku promenu pejzažne onomastike, pri čemu značajnu ulogu imaju: pojedinci i društvo, državna uprava, lokalne samouprave, preduzetnička i civilna sfera. U dvojezičnom društvu imena koja su istaknuta na manjinskim jezicima povećavaju prestiž manjinskih jezika, predstavljaju izraz kolektivnog identiteta, imaju funkciju obeležavanja etničkog identiteta i predstavljaju simbole identiteta. Ključne reči: semiotika pejzažne onomastike, društvo, identitet, dvojezično mađarskoslovačko okruženje 